\title{
STRATEGI COOVERATIVE LEARNING DALAM PERSPEKTIF PENDIDIKAN ISLAM
}

Oleh:

\section{Husin}

(Dosen, Sekolah Tinggi Ilmu Alquran Amuntai, Kalimantan Selatan)

husin@stiq-amuntai.ac.id

Bahrul Ilmi

(Mahasiswa, Prodi PGMI STIQ Amuntai, Kalimantan Selatan)

\begin{abstract}
Abstrak
Penelitian ini dilatarbelakangi atas pengamatan peneliti atas beberapa teori pendidikan yang berkembang di kalangan pendidik, dan beragamnya penerapan dari teori-teori tersebut sehingga juga menghasilkan beragamnya hasil dari kualitas pendidikan yang dilaksanakan. Strategi Cooverative Learning menjadi pilihan menarik bagi peneliti untuk dikaji dan dianalisis melalui pendekatan normative-teologis. Dengan menggunakan metode kualitatif dan analisis ayat secara tahlili, surah alMaidah ayat 2 dan al-Hujurat ayat 13 ternyata bisa mewakili teori Cooverative Learning dalam pendidikan Islam. Hasil penelitian menunjukkan bahwa nilai-nilai Cooverative Learning yang terdapat pada kedua surah tersebut seperti prinsip dasar dalam menjalin kerjasama dan saling membantu selama tujuannya adalah kebaikan dan ketakwaan, baik secara kelompok maupun perseorangan sangat sejalan dengan teori Cooverative Learning yang dipahami oleh para pendidik. Hasil dari penelitian ini diharapkan dapat memperkaya teori Cooverative Learning tersebut dengan nilai-nilai pendidikan Islam sehingga bisa menghasilkan pendekatan yang lebih Islami, sekaligus bisa menanamkan karakter religius bagi anak sebagai salah satau karakter yang harus ditanamkan oleh pendidik kepada siswa.
\end{abstract}

Kata kunci: Strategi, Cooverative Learning, Pendidikan Islam

\section{A. Pendahuluan}

Pendidikan merupakan usaha yang sengaja dan terencana untuk membantu perkembangan potensi dan kemampuan anak agar bermanfaat bagi kepentingan hidupnya sebagai seorang individu dan sebagai warga negara/masyarakat, dengan memilih isi (materi), strategi kegiatan, dan teknik penilaian yang sesuai. Penyelenggaraan pendidikan di sekolah yang melibatkan guru sebagai pendidik dan siswa sebagai siswa, diwujudkan 
dengan adanya interaksi belajar mengajar atau proses pembelajaran. Dalam konteks ini, guru dituntut untuk membentuk suatu perencanaan kegiatan pembelajaran sistematis yang berpedoman pada kurikulum yang saat itu digunakan.

Agar tujuan pendidikan tercapai dengan baik, sebagai seorang guru harus pandai memilih sebuah model pembelajaran yang bisa membuat siswa dapat mengatasi sebuah kesulitan memahami materi. Memilih model dan teknik yang digunakan memang memerlukan keahlian tersendiri. Seorang pendidik harus pandai memilih model dan teknik yang akan digunakan. Sebelum menentukan model pembelajaran ada beberapa hal yang perlu dipertimbangkan, salah satunya adalah pertimbangan dari sudut siswa, apakah model pembelajaran itu sesuai dengan minat, bakat, dan kondisi $\operatorname{siswa}^{1}$.

Salah satu model yang dipertimbangkan adalah model Cooverative Learning. Strategi pembelajaran kooperatif atau gotong royong (Cooverative Learning) adalah strategi yang menggunakan beberapa kelompok yang bekerja sama antara satu siswa dengan siswa lain dalam beberapa kelompok dengan tujuan untuk memecahkan masalah².

Dalam Alquran, Allah Subhanallahu Wa Ta'ala. Menyatakan: “Dan tolong-menolonglah kamu dalam (mengerjakan) kebajikan dan takwa, dan janganlah kamu tolong-menolong dalam berbuat dosa dan pelanggaran. Dan bertakwalah kamu kepada Allah, sesungguhnya Allah amat berat siksa-Nya (Q.S. Al-Maidah / 5:2). Konsep tolong menolong sebagaimana yang dianjurkan oleh Alquran tersebut telah dipraktekkan oleh Rasulullah Shallallahu 'Alaihi Wa Sallam. Beliau sangat memerhatikan nasib orangorang yang kurang beruntung seperti para budak, orang-orang miskin, orangorang bodoh, kaum wanita dan sebagainya. Dalam kaitannya dengan konsep 134.

${ }^{1}$ Rusman, Model-Model Pembelajaran, Cet. II (Jakarta:Rajawali Pers, 2013), h.

${ }^{2}$ Rudi Hartono, Ragam Model Mengajar yang Mudah Diterima Murid, Cet. II (Jogjakarta: DIVA Press, 2014), h. 100.

Jurnal Ilmiah AL-MADRASAH, Vol. 3, No. 1, Juli-Desember 2018 
interaktif dan Cooverative Learning ini, Rasulullah Shallallahu 'Alaihi Was sallam. Misalnya, sering meminta pendapat para sahabat dalam ikut memecahkan masalah. Ketika perang Uhud akan dilaksanakan misalnya, Rasulullah Shallallahu 'Alaihi Wa sallam. minta pendapat para sahabat tentang strategi yang akan diterapkan. Sebagian sahabat ada yang mengusulkan perang kota, dan sebagian lainnya menganjurkan perang terbuka. Rasulullah Shallallahu 'Alaihi Wa sallam kemudian mengambil pendapat yang terbanyak, yaitu perang secara terbuka ${ }^{3}$.

Berdasarkan hal di atas, peneliti tertarik untuk meneliti secara sistematis salah satu strategi Rasulullah Shallallahu 'alaihi Wa sallam dalam mengajar yaitu dengan menggunakan strategi Cooverative Learning dalam pendidikan Islam. Hal ini karena adanya ayat Alquran serta adanya Hadits Nabi yang berhubungan dengan pembelajaran Cooverative Learning sehingga peneliti melakukan penelitian ini dengan judul "Strategi Cooverative Learning dalam Perspektif Pendidikan Islam".

\section{B. Metode Penelitian}

Metode penelitian merupakan cara yang digunakan untuk menemukan, mengembangkan, menguji kebenaran suatu pengetahuan yang dilakukan dengan menggunakan metode ilmiah. Secara umum metode penelitian diartikan sebagai cara ilmiah untuk mendapatkan data dengan tujuan dan kegunaan tertentu ${ }^{4}$. Dalam penelitian ilmiah, metode menjadi penting karena metode merupakan cara bertindak, dalam upaya agar kegiatan penelitian dapat terlaksana dan mencapai hasil yang maksimal.

a. Jenis Penelitian

Jenis penelitian ini adalah penelitian library research (penelitian pustaka), yaitu jenis penelitian yang berusaha menghimpun data penelitian

${ }^{3}$ Abuddin Nata, Perspektif Islam tentang Strategi Pembelajaran, Cet. III (Jakarta: Kencana Prenadamedia Group, 2014), h. 277-278.

${ }^{4}$ Sugiyono, Metode Penelitian Pendidikan Pendekatan kuantitatif, kualitatif, dan $R \& D$ ( Bandung: Alfabeta, 2010), h. 3.

Jurnal Ilmiah AL-MADRASAH, Vol. 3, No. 1, Juli-Desember 2018 
dari khazanah literature dan menjadikan "dunia teks" sebagai obyek utama analisisnya. Maksudnya mengumpulkan data dengan cara membaca, memahami, menelaah, dan menganalisa buku-buku atau tulisan-tulisan baik dari kitab, buku, majalah, surat kabar, mengakses situs-situs internet. ${ }^{5}$

b. Metode Pengumpulan Data

Dalam penelitian ini, metode yang digunakan dalam pengumpulan data dengan metode dokumentasi. Metode dokumentasi adalah mencari data mengenai hal-hal yang variable yang berupa catatan atau tulisan, buku, surat kabar, majalah dan lain sebagainya. Adapun sumber data yang menjadi acuan dari penelitian ini adalah sebagai berikut:

1) Sumber Data Primer

Adapun sumber data primer dalam penelitian ini adalah beberapa buah kitab tafsir yang sudah dikenal di kalangan masyarakat akademis muslim. Kitab-kitab tafsir ini merupakan galian utama yang akan memberikan ulasan makna tekstual maupun makna kontekstual, terutama mengenai nilai-nilai Cooverative Learning dalam Surah Al-Maidah Ayat 2 dan Al-Hujarat Ayat 13 sebagai objek penelitian.

2) Sumber Data Sekunder

Sumber Data Sekunder, yaitu data yang berorientasi pada data yang mendukung secara langsung maupun tidak langsung yang berkaitan dengan subjek penelitian. Adapun sumber data sekunder dalam penelitian ini adalah buku-buku atau karya ilmiah lain yang isinya dapat melengkapi data yang diperlukan peneliti dalam penelitian ini. Data sekunder berupa dokumen-dokumen dan buku-buku yang menunjang dalam mempertajam hasil penelitian.

${ }^{5}$ Husin, "Fathering Adversity Management”, Al Qalam, Vol. 12, No. 2 (2018)

Jurnal Ilmiah AL-MADRASAH, Vol. 3, No. 1, Juli-Desember 2018 


\section{Hasil dan Pembahasan}

Cooverative Learning merupakan bentuk pembelajaran dengan cara siswa belajar dan bekerja dalam kelompok-kelompok kecil secara kolaboratif yang anggotanya terdiri dari empat sampai dengan enam orang dengan struktur kelompok yang bersifat heterogen. Menurut Tom V. Savage sebagaimana dikutip oleh Rusman ${ }^{6}$, Cooverative Learning yaitu: suatu pendekatan yang menekankan kerjasama dalam kelompok. Dalam Cooverative Learning proses pembelajaran tidak harus belajar dari satu sumber saja (guru) akan tetapi siswa juga dapat saling membelajarkan sesama siswa lainnya. Pembelajaran oleh rekan sebaya (peer teaching) lebih efektif daripada pembelajaran oleh guru.

Menurut Robert E. Slavin ${ }^{7}$ metode Cooverative Learning, para siswa akan duduk bersama dalam kelompok yang beranggotakan empat orang utnuk menguasai materi yang disampaikan oleh guru. Sedangkan menurut Johnson dalam B. Santoso Cooverative Learning adalah kegiatan belajar mengajar secara kelompok-kelompok kecil, siswa belajar dan bekerjasama untuk sampai pada pengalaman belajar dan bekerjasama untuk sampai pada pengalaman belajar yang optimal, baik pengalaman individu maupun kelompok ${ }^{8}$,

Metode Cooverative Learning dibangun atas dasar konstruktivis sosial dari Vgyotsky, teori Konstruktivis personal dari Piaget dan teori motivasi. Menurut prinsip utama teori Vygotsky, perkembangan pemikiran merupakan proses sosial sejak lahir. Anak dibantu oleh orang lain (baik orang dewasa maupun teman sebaya dalam kelompok) yang lebih kompeten di dalam keterampilan dan teknologi dalam kebudayaannya. Bagi Vygotsky, aktivitas kolaboratif diantara anak-anak akan mendukung pertumbuhan mereka, karena anak-anak yang sesuai lebih senang bekerja dengan orang yang satu zona (Zone

${ }^{6}$ Rusman, Model-model pembelajaran (Jakarta: PT. Raja Grafindo Persada, 2012), h. 203.

${ }^{7}$ Robert E. Slavin, Cooverative Learning Teori, Riset \& Praktik, (Bandung: Nusa Media, 2012), h. 8.

${ }^{8} \mathrm{~B}$ Santos, "Cooperative Learning: Penerapan Teknik Jigsaw Dalam Pembelajaran Bahasa Indonesia di SLTP”, Buletin Pelangi Pendidikan. Vol. 1. No. 1 (1996), h. 6. 
of Proximal Devolopment, ZPD) dengan yang lain. Pada pandangan ini, bahwa kepribadian atau kejiwaan dari pada peserta diteropong secara keseluruhan, artinya bagian atau elemen kejiwaan tidak berdiri sendiri, melainkan terorganisir menjadi satu keseluruhan.

Secara sederhana teori konstruktivisme itu beranggapan bahwa pengetahuan merupakan konstruksi dari mengetahui sesuatu. Pengetahuan kita bukanlah suatu fakta yang tinggal ditemukan, melainkan suatu perumusan atau formulasi yang dibuat oleh seseorang yang mempelajarinya ${ }^{9}$ Teori Konstruktivisme tidak bertujuan mengerti tentang realitas, tetapi lebih hendak melihat bagaimana suatu proses, dalam hal ini adalah pembelajaran, dari tidak mengetahui menjadi mengetahui sesuatu tersebut. Maka dalam pandangan ini belajar merupakan suatu proses aktif dari peserta didik untuk mengkontruksi makna, pengalaman fisik dan sebagainya.

Sedangkan Piaget juga melihat pentingnya hubungan sosial dalam membentuk pengetahuan ${ }^{10}$ Interaksi kelompok berbeda secara kualitatif dan juga lebih kuat dari pada interaksi orang dewasa dan anak-anak dalam mempermudah perkembangan kognitif. Posisi teori Piaget dalam belajar kooperatif ditujukan terutama kepada siswa yang berkemampuan tinggi agar mampu membangun pengetahuan sendiri melalui interaksi dengan lingkungan. Sebab, lingkungan insani maupun lingkungan fisik merupakan sumber yang berpengaruh terhadap perkembangan kepribadian dan kemampuan peserta didik.

Setiap model pembelajaran memiliki kelebihan dan kekurangan. Demikian pula dengan Cooverative Learning. Dalam Cooverative Learning, guru melakukan pemantauan terhadap kegiatan peserta didik, mengarahkan keterampilan kerja sama dan memberikan bantuan pada saat diperlukan. Aktivitas belajar berpusat pada peserta didik, guru berfungsi sebagai fasilitator

\footnotetext{
${ }^{9}$ Sardiman A. M, Interaksi dan Motivasi Belajar Mengajar, (Jakarta: PT. Raja Grafindo Persada, 2007), h. 37.

${ }^{10}$ Muhibbin Syah, Psikologi Pendidikan Dengan Pendekatan Baru, (Bandung: PT. Remaja Rosdakarya.2002), h. 74
} 
dan dinamisator. Dengan sistem ini diharapkan peserta didik dapat mengembangkan semua potensinya secara optimal dengan cara berpikir aktif selama proses belajar ${ }^{11}$ Salah satu kelebihan strategi pembelajaran kooperatif adalah peserta didik lebih memperoleh kesempatan dalam hal meningkatkan hubungan kerja sama antar-teman dan diantara kekurangannya adalah jika peserta didik belum terbiasa dan menguasai belajar kooperatif, pencapaian hasil belajar tidak akan maksimal.

Dalam Q.S. Al-Maidah / 5:2 Allah swt. berfirman :

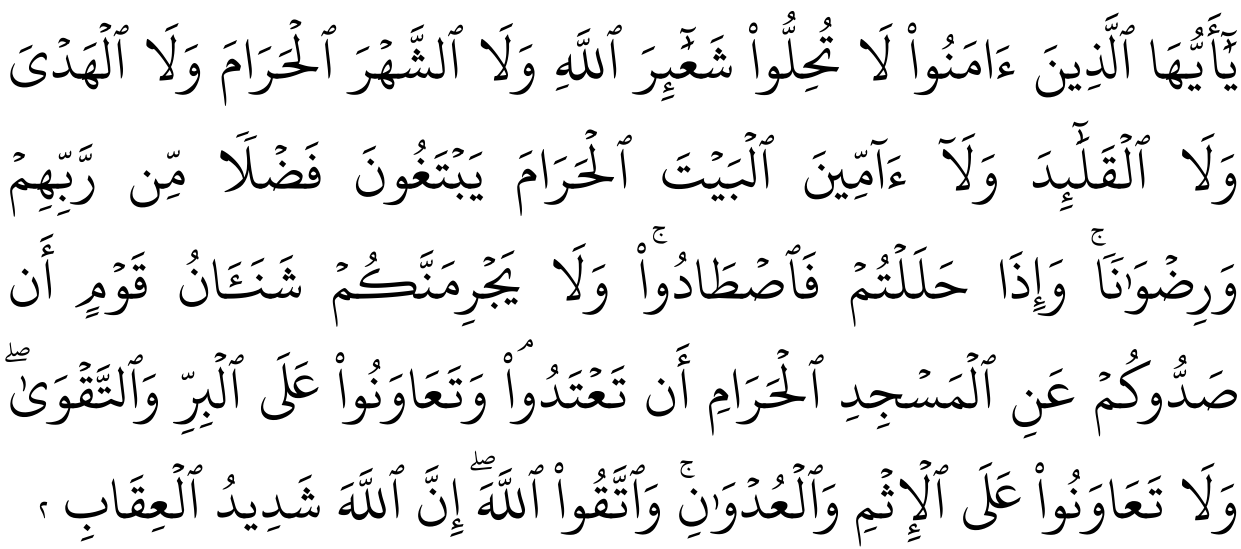

Artinya : Hai orang-orang yang beriman, janganlah kamu melanggar syíarsyi'ar Allah, dan jangan melanggar kehormatan bulan-bulan haram, jangan (mengganggu) binatang-binatang had-ya, dan binatang-binatang qalaa-id, dan jangan (pula) mengganggu orang-orang yang mengunjungi Baitullah sedang mereka mencari kurnia dan keridhaan dari Tuhannya dan apabila kamu telah menyelesaikan ibadah haji, maka bolehlah berburu. Dan janganlah sekali-kali kebencian(mu) kepada sesuatu kaum karena mereka menghalang-halangi kamu dari Masjidilharam, mendorongmu berbuat aniaya (kepada mereka). Dan tolong-menolonglah kamu dalam (mengerjakan) kebajikan dan takwa, dan jangan tolong-menolong dalam berbuat dosa dan pelanggaran. Dan bertakwalah kamu kepada Allah, sesungguhnya Allah amat berat siksa-Nya

${ }^{11}$ Jamil Suprihatiningrum, Strategi Pembelajaran (teori dan aplikasi), Cet. III (Jogjakarta: AR-RUZZ MEDIA, h. 200. 
Ibnu Jarir meriwayatkan dari Ikrimah, dia berkata, "Al-Hutham bin Hinduwal Bakri datang ke Madinah dengan beberapa untanya yang membawa bahan makanan untuk di jual. Kemudian dia mendatangi Rasulullah, dan menawarkan barang dagangannya, setelah itu dia masuk Islam. Ketika dia keluar dari tempat Rasulullah, beliau bersabda kepada orang-orang yang ada di dekat beliau "Dia datang kepadaku dengan wajah orang yang jahat. Lalu ia pergi punggung seorang pengkhianat."Ketika Al-Hutham sampai Yamamah, dia keluar dari Islam (murtad). Ketika bulan Dzulhijjah, dia pergi ke Mekkah dengan rombongan untanya yang membawa bahan makanan. Ketika orangorang Muhajirin dan orang-orang Anshar mendengar berita kepergian AlHutham ke Mekkah, mereka pun bersiap-siap untuk menyerang kafilah untanya. Maka Allah Shubhanallahu Wa Ta'ala menurunkan firmannya (Al-Maidah ayat 2).

Akhirnya mereka tidak jadi melakukan hal itu, Ibnu Jarir juga meriwayatkan dari Zaid bin Aslam, dia berkata, "Rasulullah dan para sahabat berada di hudaibiyah ketika orang-orang musyrik menghalangi mereka pergi ke Baitullah. Hal ini membuat marah para sahabat. Ketika dalam keadaan demikian, beberapa orang musyrik dari daerah timur melintasi mereka menuju Baitullah untuk melakukan umrah. Para sahabat berkata, "Kita halangi mereka agar tidak pergi ke Baitullah, sebagaimana mereka menghalangi kita”. Lalu Allah Subhanallahu Wa Ta'ala menurunkan firman-Nya:

“jangan saampai kebencianmu kepada suatu kaum karena mereka menghalanghalangi dari Masjidil haram..." 12

Islam mengajarkan bahwa kemarahan atau kebencian itu mutlak hak diri setiap manusia, namun ajaran tersebut memberi kewajiban agar dengan adanya kemarahan dan kebencian tersebut tidak memicu perbuatan menganiaya ataupun menindas yang lainnya. Suatu perbuatan yang tidak baik hendaklah tidak memicu perbuatan menganiaya ataupun menindas yang lainnya. Suatu

\footnotetext{
${ }^{12}$ M. Quraish Shihab (eds), Ensiklopedia Al-Qur'an: Kajian Kosakata (Jakarta: Lentera Hati, 2007), h. 960.
}

Jurnal Ilmiah AL-MADRASAH, Vol. 3, No. 1, Juli-Desember 2018 
perbuatan yang tidak baik hendaklah tidak dibalas dengan hal yang tidak baik juga

Rasulullah Shallallahu 'Alaihi Wasallam pun juga mengajarkan bahwa setiap kebaikan yang dilakukan juga akan dibalas dengan kebaikan oleh Allah Shubhanallahu Wa Ta'ala, dengan tidak membalas suatu kejahatan yang dilakukan orang lain sama halnya dengan menutup kesalahan orang lain karena sejatinya dalam ajaran Islam yang dibawa Rasulullah Shallallahu 'Alaihi Wasallam mengajarkan setiap individu untuk saling memberi pertolongan dalam kebaikan bukan keburukan, menutup cela orang lain bukan mengumbarumbarkannya.

Begitu pula dalam segi kemanusiaan, menolong merupakan kesediaan seseorang dalam hal memberikan bantuan. Secara sadar, orang mulai memberikan bantuan adalah yang bergerak hatinya. Karena dalam diri manusia memiliki rasa empati, rasa merasakan apa yang orang lain rasakan dan dengan itu tergeraklah hatinya untuk menolong orang lain serta pada hakikatnya manusia merupakan makhluk sosial. Makhluk yang tidak mampu memenuhi keperluannya sendiri, yang tidak hidup tanpa bantuan orang lain ${ }^{13}$

Tidak ada satu keperluan manusia yang dapat di atasi oleh dirinya sendiri. Seorang penjual perlu pembeli, seorang guru perlu murid, seorang penjual perlu pembeli, seorang guru perlu murid, seorang pemilik pabrik perlu karyawan, dan seterusnya. Untuk memenuhi keperluan tersebut, maka Islam menganjurkan agar di antara manusia saling menolong secara konstukritf, produktif dan positif. Dalam Al-Qur'an, Allah SWT. Menyatakan: “Dan tolongmenolonglah kamu dalam (mengerjakan) kebajikan dan takwa, dan janganlah kamu tolong-menolong dalam berbuat dosa dan pelanggaran. Dan bertakwalah kamu kepada Allah, sesungguhnnya Allah amat berat siksa-Nya (QS. AlMaidah, 5: 2).

\footnotetext{
${ }^{13}$ Muhammad Mustari, Nilai Karakter Refleksi untuk Pendidikan (Jakarta: PT. Raja Grafindo Persada, 2014), h. 184.
} 
Dalam Tafsir Al-Mishbah, Quraish Shihab menyatakan bahwa ayat inilah yang menjadi prinsip dasar dalam menjalin kerjasama dan saling membantu selama tujuannya adalah kebaikan dan ketakwaan ${ }^{14}$

Maka jelasnya ayat ini sangat mendukung adanya model Cooverative Learning di mana ide dasar dalam model ini adalah kerjasama dan saling bantu membantu dalam proses belajar mengajar untuk mendapatkan pengetahuan bersama. Dari ayat di atas maka dapat diketahui bahwa prinsip kerjasama dan saling membantu dalam kebajikan dan sangat dianjurkan oleh agama Islam.

Konsep tolong menolong sebagaiman yang dianjurkan oleh Al-Qur'an tersebut telah dipraktekkan oleh Rasulullah Shallallahu 'Alaihi Wa Sallam. Beliau amat memperhatikan nasib orang-orang yang kurang beruntung seperti para budak, orang-orang miskin, orang-orang bodoh, kaum wanita dan sebaginya. Dalam kaitannya dengan konsep interaktif dan Cooveratif learning ini, Rasulullah Shallallahu 'Alaihi Wa Sallam. misalnya, sering meminta pendapat para sahabat dalam ikut memecahkan masalah. Ketika perang Uhud akan dilaksanakan, Rasulullah Shallallahu 'Alaihi Wa Sallam. minta pendapat para sahabat tentang strategi yang akan diterapkan. Sebagian sahabat ada yang mengusulkan perang kota, dan sebagian lainnya menganjurkan perang terbuka. Rasulullah Shallallahu 'Alaihi Wa Sallam. kemudian mengambil pendapat yang terbanyak, yaitu perang secara terbuka.

Dalam hadits yang beliau kemukakan, juga dijumpai ajaran tentang konsep belajar interaktif dan kooperatif ini. Misalnya, haditsnya yang artinya "Pelajarilah olehmu ilmu pengetahuan, dan ketahuilah, bahwa pada setiap ilmu itu ada ketenangan dan kehalusan, dan bersikap rendah hatilah terhadap orang-orang yang kamu sekalian belajar darinya." (HR. Abu Na'im dari Ibn Umar)

Pada hadits ini, kita dianjurkan agar mempelajari ilmu pengetahuan dan menjadikannya sebagai penghias diri agar orang yang santun dan beradab, dan cet III, h. 13 .

${ }^{14}$ M. Quraish Shihab, Tafsir Al-Mishbah Vol 3 (Jakarta: Lentera Hati, 2002), 
juga menghormati kepada setiap orang yang mengajarkan ilmu tersebut. Dalam hadits terdapat petunjuk adanya konsep tutor sebaya, yakni menjadi teman sejawat yang memilki pengetahuan sebagai guru, dan sebaliknya pengetahuan yang kita miliki untuk diajarkan pada orang lain ${ }^{15}$

Jadi Surah Al-Maidah ayat 2 berhubungan dengan Cooverative Learning karena memuat salah satu nilai dari Cooverative Learning yaitu tentang tolong menolong dalam hal kebaikan, salah satu tolong menolong dalam kebaikan adalah menolong seseorang dalam menuntut ilmu seperti cara mengajari seseorang yang tidak dipahami oleh orang tersebut, sehingga ada proses tukar pikiran diantara individu-individu dalam kelompok tersebut sehingga menuju terciptanya sintesis dalam kesimpulan yang sesuai dengan materi yang dibahas.

Dalam Q.S. Al-Hujurat / 49:13 Allah swt. berfirman :

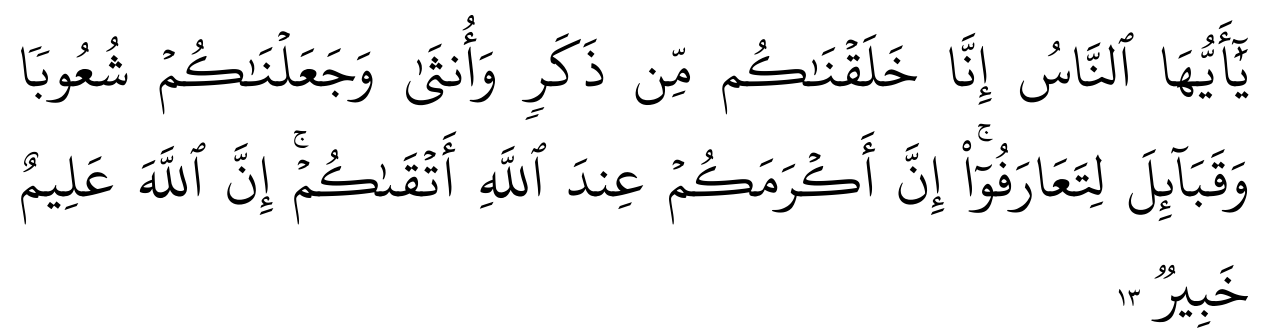

Artinya : Hai manusia, Sesungguhnya Kami menciptakan kamu dari seorang laki-laki dan seorang perempuan dan menjadikan kamu berbangsa - bangsa dan bersuku-suku supaya kamu saling kenal-mengenal. Sesungguhnya orang yang paling mulia diantara kamu disisi Allah ialah orang yang paling taqwa diantara kamu. Sesungguhnya Allah Maha mengetahui lagi Maha Mengenal.

Ibnu Abu Hatim telah mengetengahkan sebuah hadits melalui Ibnu Abu Mulaikah yang telah menceritakan bahwa ketika penaklukan kota Mekkah, Bilal langsung naik ke atas Ka'bah, kemudian mengumandangkan suara adzan. Lalu sebagian orang mengatakan: "Apakah hamba sahaya yang hitam ini berani adzan di atas Ka’bah?" Sebagian dari mereka mengatakan: "Jika Allah

\footnotetext{
${ }^{15}$ Abuddin Nata, Perspektif Islam tentang Strategi Pembelajaran cet III (Jakarta: Kencana Prenadamedia Group, 2014), , h. 277-279.
}

Jurnal Ilmiah AL-MADRASAH, Vol. 3, No. 1, Juli-Desember 2018 
Husin: Strategi Cooverative Learning dalam Perspektif Pendidikan Islam

Shubhanallahu Wa Ta'ala murka, niscaya Dia akan mencegahnya". Lalu Allah Shubhanallahu $\mathrm{Wa}$ Ta'ala menurunkan firmannya "Hai manusia,sesungguhnya Kami mencinptakan kalian dari seorang laki-laki dan seorang perempuan...” (QS. Al-Hujurat / 49:13)

Ibnu Asakir di dalam kitab Mubhamat-nya telah mengatakan, "Aku telah menemukan di dalam manuskrip yang di tulis oleh Ibnu Bayskuwal bahwa Abu Bakar Ibnu Daud telah mengetengahkan sebuah hadits di dalam kitab tafsir yang di tulisnya, bahwa ayat ini diturunkan berkenaan dengan Abu Hindun. Rasulullah Shallallahu 'Alaihi Wasallam memerintahkan kepada Bani Bayyadah supaya mereka mengawinkan Abu Hindun dengan seorang wanita dari kalangan mereka. Lalu mereka menjawab: "Wahai Rasulullah, apakah pantas bila kami menikahkan anak-anak perempuan kami dengan bekas hamba sahaya kami? Lalu turunlah ayat ini" 16

Dalam sumber lain juga menjelaskan bahwa sebab turunnya QS. AlHujurat ayat 13 diinformasikan oleh Ibnu Abi Hatim dari Ibnu Abi Mulaikah, bahwa: "Ketika terjadi peristiwa penalukkan kota Mekkah (yaumul-fath), naiklah Bilal bin Rabah ke atap puncak Ka'bah mengujar: "Kenapa seorang budak hitam legam ini mengumandangkan adzan di atap puncak Ka'bah? Semoga Allah Subhanallahu Wa Ta'ala memurka dan menggantinya”, Maka, turunlah ayat ini untuk membantah pernyataan orang tersebut.

Dalam Cooverative Learning, selain dituntut untuk mempelajari materi yang diberikan seorang siswa dituntut untuk belajar bagaimana berinteraksi dengan siswa lain dalam kelompoknya. Bagaimana siswa bersikap sebagai anggota kelompak dan menyampaikan ide dalam kelompok akan menuntuk keterampilan khusus.

Ketergantungan manusia terhadap sesamanya atau berinteraksi rupanya juga menjadi salah satu tuntunan dalam ajaran Islam dimana sebenarnya

\footnotetext{
${ }^{16}$ Imam Jalaluddin Al-Mahalli, Tafsir Al-Jalalain, terj, Bahrun Abubakar, Lc (Bandung: Sinar Baru Algesindo, 2008), h. 904.
}

Jurnal Ilmiah AL-MADRASAH, Vol. 3, No. 1, Juli-Desember 2018 
manusia diciptakan oleh Allah di muka bumi ini untuk dapat saling mengenal dan tolong menolong.

Dalam hal kerjasama, sebenarnya Islam juga memerintahkan umatnya untuk saling tolong-menolong dan bekerjasama dalam kebaikan dan manfaat. Lebih lagi terhadap sesama umat Islam. Bahkan Islam mengibaratkan persaudaraan dan pertalian sesama muslim itu seperti satu bangunan, dimana struktur dan unsur bangunan itu saling memerlukan dan melengkapi, sehingga menjadi sebuah bangunan yang kokoh, kuat dan bermanfaat lebih

Pada ayat di atas, Allah menyebutkan Dia (Allah) telah menciptakan anak Adam dari satu permulaan dan jenis yang sama, dari seorang lelaki dan perempuan, yaitu Adam dan Hawa. Kemudian dari keduanya, Allah mengembangbiakkan laki-laki dan perempuan yang banyak dan menyebarkan mereka ke tempat-tempat yang berbeda-beda ${ }^{17}$

Hamka dalam tafsir Al-Azhar menafsirkan pada bagian awal ayat ini boleh ditafsirkan dengan dua tafsiran yang keduanya nyata dan tegas. Pertama ialah bahwa seluruh manusia dijadikan pada mulanya dari seorang laki-laki yaitu Nabi Adam dan seorang perempuan yaitu Siti Hawa. Beliau berdualah manusia yang mulanya diciptakan dalam dunia ini. Selanjutnya, boleh ditafsirkan dengan sederhana bahwa manusia dari dulunya sampai sekarang terjadi dari seorang laki-laki dan seorang perempuan yaitu Ayah dan Ibu. Kemudian pada pertengahan ayat ditafsirkan bahwa dengan terjadinya berbagai bangsa, berbagai suku, dan berbagai keluarga bertujuan agar manusia saling mengenal satu sama lain. Serta pada bagian akhir ayat Allah menegaskan bahwa yang paling mulia di sisi Allah adalah manusia yang taqwa. Seseungguhnya Allah Maha mengetahui maha teliti ${ }^{18}$

Jadi surah Al-Hujurat berkaitan dengan Cooverative Learning karena memuat salah satu nilai dari Cooverative Learning yaitu dalam surah Al-

\footnotetext{
${ }^{17}$ Lihat Al-Qurthubi, Al-Jami li Ahkamil Qur'an, juz XVI dan 292; Ibnu Katsir, Tafsirul Qur'amil Azhim, juz VII, hal. 385, As-Sa'di, Taisiril Karimir Rahman, h. 880 dan Asy-Syinqithi, Adlayaul Bayan, Juz VII, h. 631.

${ }^{18}$ Hamka, Tafsir Al-Azhar Jilid 8, (Jakarta: Gema Insani, 2015), h. 430-432.
} 
Hujurat tersebut secara tidak langsung menjelaskan tentang kelompok karena manusia itu diciptakan dari seorang laki-laki dan seorang wanita, dan manusia dijadikan berbangsa-bangsa dan bersuku-suku agar saling kenal mengenal, seperti mengenal identitas, bahasa, kebudayaan, maupun pengalaman seseorang. Adanya proses kenal mengenal dapat membuat komunikasi antara individuindividu dalam kelompok belajar Cooverative Learning terbuka sehingga kesulitan-kesulitan dapat diceritakan dan lewat perantara tersebut dicari pemecahan masalah secara bersama.

\section{Simpulan}

Menurut Johnson dalam B. Santoso Cooverative Learning adalah kegiatan belajar mengajar secara kelompok-kelompok kecil, siswa belajar dan bekerjasama untuk sampai pada pengalaman belajar dan bekerjasama untuk sampai pada pengalaman belajar yang optimal, baik pengalaman individu maupun kelompok.

Berdasarkan tafsiran ayat di atas maka dapat diperoleh kesimpulan bahwa nilai-nilai Cooverative Learning terdapat di dalam Alquran diantaraya Surah Al-Maidah ayat 2 dan Al-Hujurat 13 karena di dalam dua ayat tersebut ada nilai-nilai Cooverative Learning seperti tolong-menolong dan bantu-membantu, berkelompok-kelompok yang mana berkorelasi satu sama lain antara teori Cooverative Learning dengan Alquran. 
Husin: Strategi Cooverative Learning dalam Perspektif Pendidikan Islam

\section{Daftar Pustaka}

Hamka, Tafsir Al-Azhar Jilid 8, Jakarta: Gema Insani. 2015.

Hartono, Rudi, Ragam Model Mengajar yang Mudah Diterima Murid, Cet. II. Jogjakarta: DIVA Press. 2014.

Husin, "Fathering Adversity Management", Al-Madrasah Vol. 3, No. 1 (2018)

Lihat Al-Qurthubi, Al-Jami li Ahkamil Qur'an, juz XVI dan 292; Ibnu Katsir, Tafsirul Qur'amil Azhim, juz VII, hal. 385, As-Sa'di, Taisiril Karimir Rahman, h. 880 dan Asy-Syinqithi, Adlayaul Bayan, Juz VII, h. 631

M, Sardiman A, Interaksi dan Motivasi Belajar Mengajar. Jakarta: PT. Raja Grafindo Persada. 2007.

Nata, Abuddin, Perspektif Islam tentang Strategi Pembelajaran, Cet. III. Jakarta: Kencana Prenadamedia Group. 2014.

Rusman, Model-Model Pembelajaran, Cet. II. Jakarta:Rajawali Pers. 2013.

Santos B, Cooperative Learning: Penerapan Teknik Jigsaw Dalam Pembelajaran Bahasa Indonesia di SLTP. Buletin Pelangi Pendidikan Vol. 1. No. 1. 1996.

Shihab, M. Quraish, Tafsir Al-Mishbah Vol 3. Jakarta: Lentera Hati. 2002.

Sugiyono, Metode Penelitian Pendidikan Pendekatan kuantitatif, kualitatif, dan $R \&$ D. Bandung: Alfabeta. 2010. Suwadi, dkk, Panduan Penulisan Skripsi. Yogyakarta: Jurusan PAI Fakultas Ilmu Tarbiyah dan Keguruan UIN Sunan Kalijaga. 2014.

Syah Muhibbin, Psikologi Pendidikan Dengan Pendekatan Baru, Bandung: PT. Remaja Rosdakarya. 2002. 
Husin: Strategi Cooverative Learning dalam Perspektif Pendidikan Islam

Jurnal Ilmiah AL-MADRASAH, Vol. 3, No. 1, Juli-Desember 2018 